\title{
Dynamics of shell disease in the edible crab Cancer pagurus: a comparative study between two sites on the Gower Peninsula, South Wales, UK
}

\author{
Claire L. Vogan, Andrew F. Rowley* \\ School of Biological Sciences, University of Wales Swansea, Singleton Park, Swansea SA2 8PP, South Wales, United Kingdom
}

\begin{abstract}
Shell disease syndrome is a degradative condition of the crustacean exoskeleton which results in the formation of black-spot lesions. Field surveys on the edible crab Cancer pagurus (L.) population at 2 sites in the Gower Peninsula of South Wales, UK, namely Langland Bay and Rhossili causeway, revealed similarities in the prevalence of shell disease but differences in the severity. Male crabs from Langland Bay displayed significantly greater severities of the disease on the dorsal carapace and ventral surfaces than those in Rhossili. The greatest severities of the disease in Langland were attributable to sand abrasion injuries during back-burrowing behaviour and prolonged exposure to high numbers of chitinolytic bacteria. Lower severities of shell disease in males from Rhossili were a reflection of the inability to back-burrow due to the nature of the onshore sediment, and hence the crabs were only exposed to low levels of chitinolytic bacteria in the water column. On areas of the causeway that permitted back-burrowing, the chitinase enzyme activities in sediments were significantly lower than those in Langland Bay. It is concluded that the potential for crustacean shell degradation is higher at Langland than Rhossili, but whether the differences in chitinolytic abilities of the sediments at the 2 sites are a result of differences in pollution levels or simply of different substratum types, remains to be determined.
\end{abstract}

KEY WORDS: Shell disease $\cdot$ Chitin degradation $\cdot$ Cancer pagurus $\cdot$ Crustacea

\section{INTRODUCTION}

Shell disease syndrome is characterised by the appearance of black-spot lesions during the progressive degradation of the exoskeletons of marine crustaceans (for review see Getchell 1989). Chitinolytic bacteria are the principal aetiological agents involved in cuticular degradation (Vogan et al. 2002). Lesion initiation, however, requires the removal of the thin non-chitincontaining epicuticular layer, and this may occur by the enzymatic activities of microorganisms (Cipriani et al. 1980), wounding or abrasive injuries (Dyrynda 1998, Vogan et al. 1999) or chemical attack (Schlotfeldt 1972). Thus, the causes of shell disease are likely to be

${ }^{*}$ Corresponding author. E-mail: a.f.rowley@swansea.ac.uk area-specific, varying according to the geographic location of the crustacean population. Elevated levels of the disease have been frequently reported in crustaceans from polluted environments (e.g. Gopalan \& Young 1975, Young \& Pearce 1975, Estrella 1990, Sawyer 1991) and aquaculture systems (e.g. DelvesBroughton \& Poupard 1976, Getchell 1991, Prince et al. 1993), suggesting that deleterious environmental situations may exacerbate the condition.

In preliminary studies, Vogan et al. (1999) reported high prevalences $(55 \%$ of crabs had exoskeletal lesions) and severities (on average $0.78 \%$ of the body was covered by lesions in diseased crabs) of shell disease in the edible crab Cancer pagurus captured on the shores of Langland Bay, Gower Peninsula, South Wales. Lesion location patterns suggested that backburrowing into sediment was an important factor in 
initiation of epicuticular abrasion. Vogan et al. suggested that lesion progression may also be enhanced by close contact between newly exposed cuticular chitin and large numbers of chitinolytic microorganisms that are reported to reside in the upper layers of sandy sediments (Hood \& Meyers 1973). The current study compares and contrasts shell disease levels in $C$. pagurus populations from Langland Bay and Worms Head Causeway (Rhossili), located on the south-western tip of the Gower Peninsula. The Rhossili sample site is believed to be less polluted than Langland Bay, largely due to its extreme location, current flows and lower coliform counts (see Environment Agency data for 1998: www.environment-agency.gov.uk). This study investigated whether sediment-associated differences (sediment structure and chitinolytic activity of the culturable microbial population) may account for differences in the levels of shell disease in C. pagurus onshore populations between the 2 sample sites.

\section{MATERIALS AND METHODS}

Field survey. Monthly shore surveys of Cancer pagurus were conducted around Langland Bay (see Fig. 1) and Worms Head, Rhossili (see Fig. 2) during the crabbing season in 1998 (1 May to 31 October). Sampling occurred on spring tides that measured less than $1.5 \mathrm{~m}$ above chart datum for Langland and $1.2 \mathrm{~m}$ above chart datum for Rhossili (these tides permitted complete access across the causeway to Worms Head; see Fig. 2). All crabs collected were sexed, their carapace width measured to the nearest millimetre, and limb loss noted. The size and position of lesions on the external surface of each crab was recorded onto a standard $C$. pagurus outline (adapted from Warner 1977) from which an estimate of the percentage of the exoskeleton covered by lesions could be calculated. Unless otherwise stated, the prevalence of shell disease is defined as the proportion of the crab population that has 1 or more exoskeletal lesions. Disease severity is defined as the percentage of the external exoskeleton covered by lesions in diseased crabs. The dorsal carapace was subdivided into 28 regions of equal area, thus enabling the precise location of dorsal carapace lesions to be mapped. Ecdysed crabs of Moult Stages A and B (according to Drach 1939) were not included in this study, because they showed no melanin expression at these stages of their moult cycle (Anderson \& Conroy 1968, Chan et al. 1988), making it difficult to assess levels of shell disease in such individuals.

Sediment structure and chitinolytic activity. Sediment samples were collected from 10 randomly chosen crab holes at both sites (i.e. Langland \& Rhossili). From

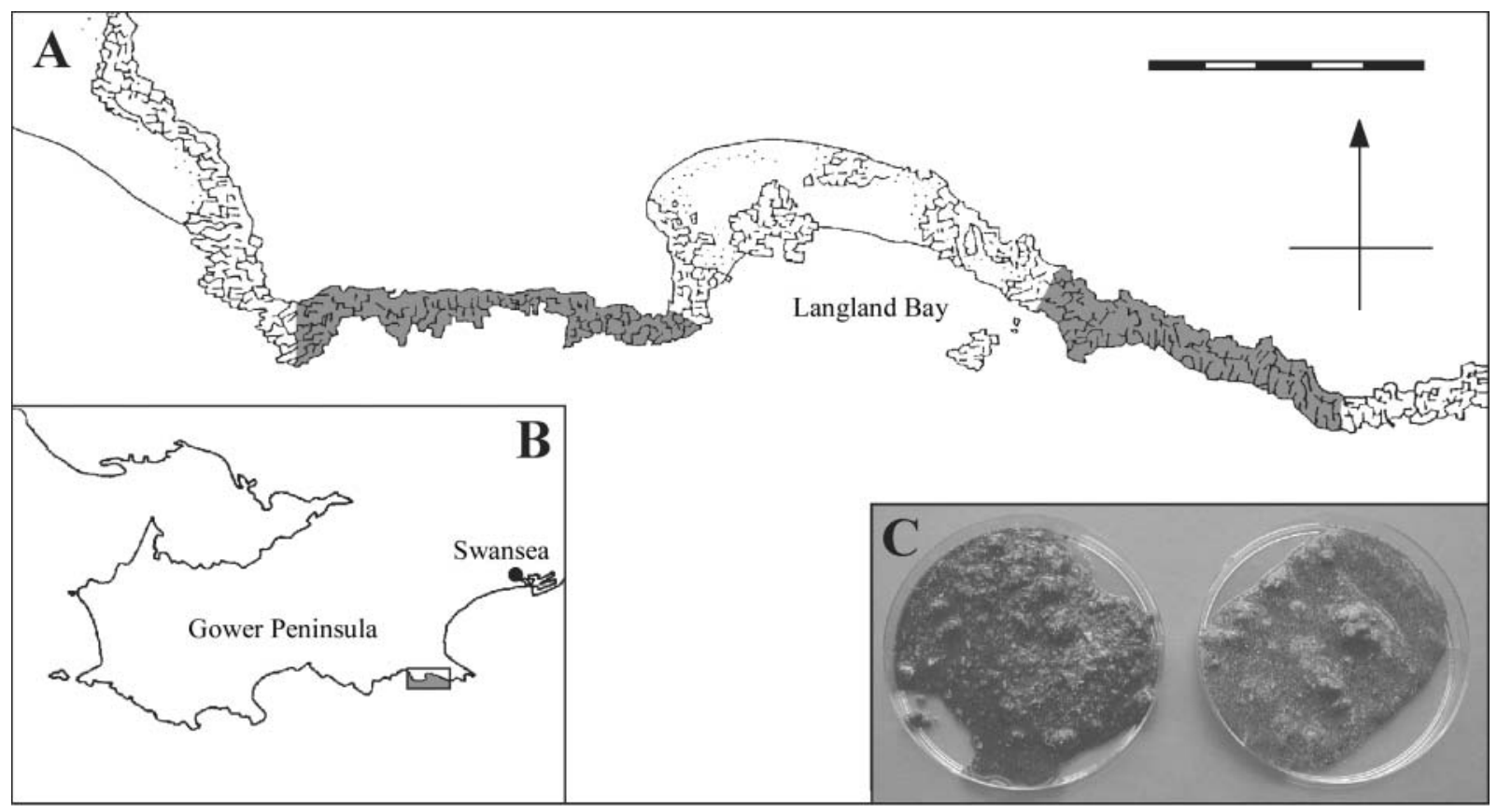

Fig. 1. Maps showing rocky shores surrounding Langland Bay (A) and its location on the Gower Peninsula (B); shaded regions in A indicate sample areas. (C) Varying degrees of black colouration indicating anoxia within sediments samples removed from crab holes in the sample area. Scale bar in $(A)=500 \mathrm{~m}$ 


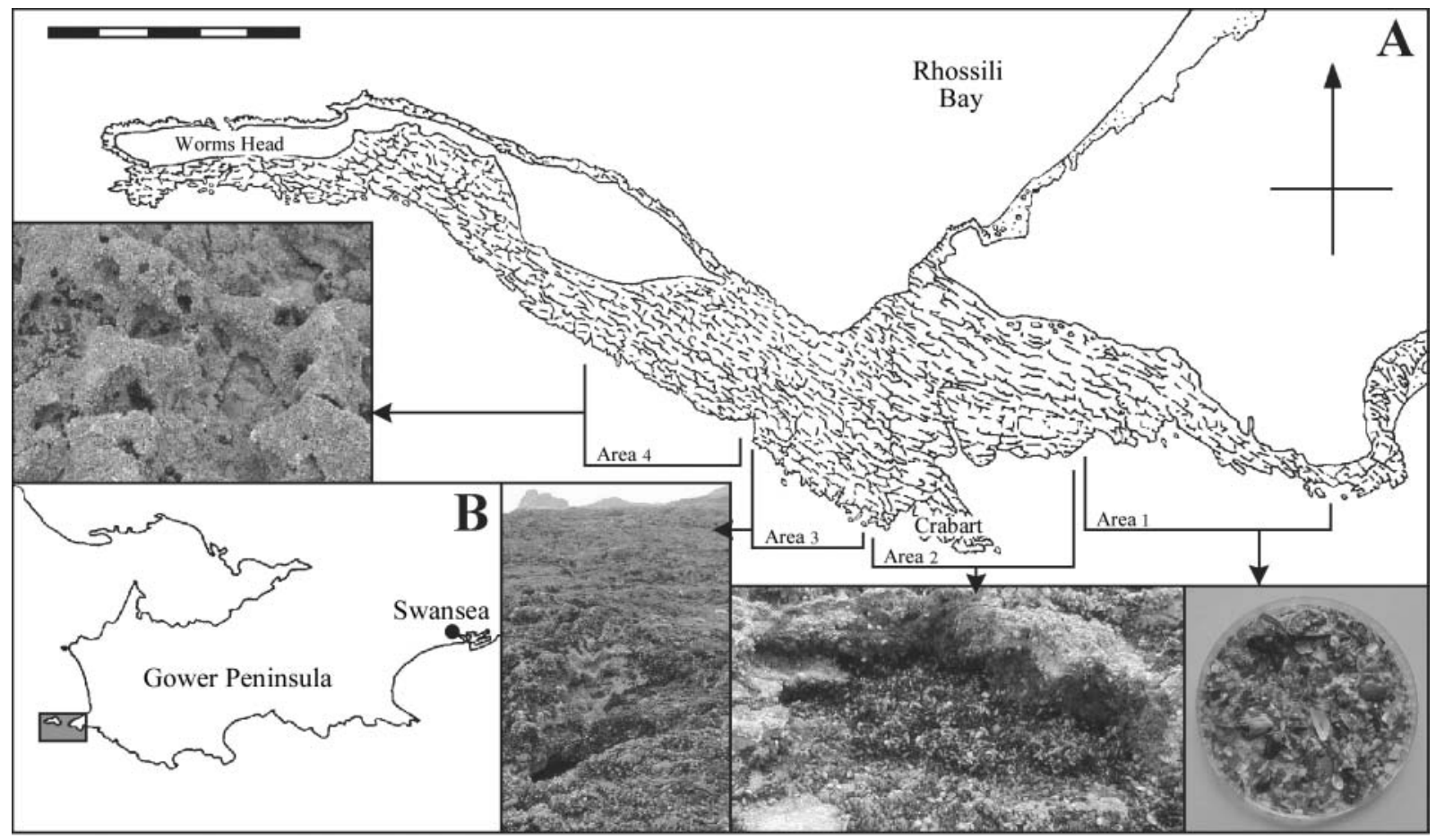

Fig. 2. Maps showing rocky causeway of Rhossili Bay sample site (A) and its location on the Gower Peninsula (B). Bracketed areas 1 to 4 in (A) indicate the specific regions sampled and their differing sediment characteristics. Scale bar in $(\mathrm{A})=500 \mathrm{~m}$

each hole, the top layer of sediment to a depth of approximately $2.5 \mathrm{~cm}$ was transferred into 2 sterile plastic screw-top universal tubes. Samples were immediately transported back to the laboratory, where half were processed under sterile conditions for estimations of chitinase activity. The remainder were stored at $-20^{\circ} \mathrm{C}$ for later photography.

Estimates of the culturable chitinase activity were obtained by aseptically adding $10 \mathrm{~g}$ of sediment to autoclaved conical flasks $(25 \mathrm{ml})$ that contained $1 \mathrm{~g}$ of chitin powder and $10 \mathrm{ml}$ of tris-buffered saline, $\mathrm{pH} 7.5$. All flasks were incubated at $25^{\circ} \mathrm{C}$ with shaking for $18 \mathrm{~d}$ to allow bacterial growth and chitinase production. After the incubation period, the flasks were agitated on a Luckham vibrator for $30 \mathrm{~min}$ followed by $1 \mathrm{~min}$ on a rotamixer; they were then centrifuged $(1800 \times g$ for $10 \mathrm{~min}$; room temperature) the supernatants filter-sterilised ( $0.2 \mu \mathrm{m}$ pore size) and aliquots from each sample supernatant heat-inactivated $\left(100^{\circ} \mathrm{C}_{i} 5 \mathrm{~min}\right)$. All enzyme and heat-inactivated samples were stored at $-20^{\circ} \mathrm{C}$ until analysis of their chitinolytic abilities.

Total chitinase activities of the sediment supernatants were determined using the p-dimethylaminobenzaldehyde (DMAB) method adapted from Yanai et al. (1992). Briefly, $250 \mu \mathrm{l}$ of each enzyme supernatant sample was incubated with $125 \mu \mathrm{l}$ of colloidal chitin and $125 \mu \mathrm{l}$ of $0.1 \mathrm{M}$ Tris- $\mathrm{HCl}$ that contained $0.08 \%$ sodium azide for $46 \mathrm{~h}$ at $25^{\circ} \mathrm{C}$. After cen- trifugation, $125 \mu \mathrm{l}$ of the supernatant were mixed with $25 \mu \mathrm{l}$ of $0.8 \mathrm{M}$ boric acid ( $\mathrm{pH} 10.2$, adjusted with $\mathrm{KOH}$ ) and the mixture heated in a boiling water bath for 3 $\min$. Once cool, $750 \mu \mathrm{l}$ of the DMAB solution $(1 \%[\mathrm{w} / \mathrm{v}]$ [Sigma], $99 \%[\mathrm{v} / \mathrm{v}]$ glacial acetic acid, $1 \%[\mathrm{v} / \mathrm{v}]$ concentrated hydrochloric acid) were added, and all samples were incubated for $20 \mathrm{~min}$ at $37^{\circ} \mathrm{C}$. Samples were plated in triplicate $(200 \mu \mathrm{l})$ onto a 96 -well microtitre plate and the optical density (OD) measured at $550 \mathrm{~nm}$. Sample blanks (containing $250 \mu \mathrm{l}$ of heat-inactivated enzyme supernatant) and negative controls (consisting of $250 \mu \mathrm{l}$ of the supernatant from sterile control cultures) were prepared in parallel. A standard curve, for the linear range of the assay, was produced using serial dilutions of $\mathrm{N}$-acetyl glucosamine and the above method. One unit of enzyme activity (U) was defined as the amount of enzyme required to produce sugars equivalent to $1 \mu \mathrm{mol} \mathrm{N}$-acetyl glucosamine $\mathrm{min}^{-1}$ under the above conditions.

Statistical analyses. Differences in the prevalences of disease between the 2 sample sites were analysed using contingency tables combined with the Fisher's exact test. All other data are shown as mean values \pm $1 \mathrm{SE}$ and analysed using the Student's $t$-test. Data were tested for normality using the Kolmogorov-Smirnov test and, when data resisted transformation to normality, the equivalent non-parametric test (Mann Whitney $U$-test) was applied. 


\section{RESULTS}

Although both sample sites comprise a rocky shoreline, they vary in the sediment type that lines the crevices and crab holes (Figs. 1 \& 2). The causeway at Rhossili has 3 main types of rock-associated substratum. The eastern reaches of the sample site (Area 1) consisted of small shell fragments (Fig. 2) (approximately 1 to $10 \mathrm{~mm}$ ). Mussel beds cover the majority of Crabart (Area 2) and shell debris from these, matted together by byssus threads, stretch about half-way back towards Worms Head (Area 3). The remainder of holes at the sample site (Area 4) are composed of bare rock. In contrast, crab holes at Langland consist primarily of sandy grain types (Fig. 1C) and many of the crabs removed from holes were covered in black anoxic sediment.

The overall prevalence of shell disease (the number of crabs from all sampled that displayed 1 or more black-spot lesions) was $60.8 \%$ in Langland and $49.0 \%$ in Rhossili. At both sample sites, males showed higher
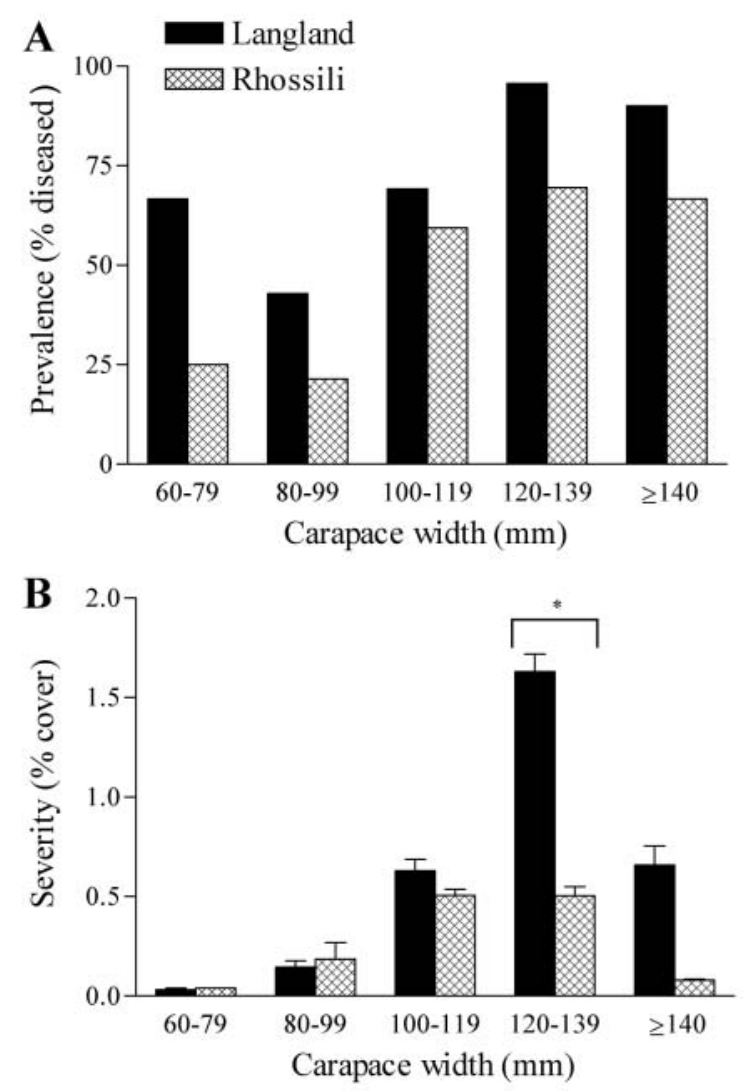

Fig. 3. Cancer pagurus. (A) Prevalence and (B) severity of shell disease in males from each size class at Langland $(\mathrm{n}=2$ to 23) and Rhossili ( $\mathrm{n}=1$ to 32 ) during the 1998 crabbing season. * Significant difference between each size class at Langland and Rhossili (Mann-Whitney $U$-test, $\mathrm{p}<0.05$ )
Table 1. Cancer pagurus. Levels of shell disease syndrome in males and females from the 2 sample sites, Langland Bay and Rhossili Causeway. ${ }^{*}$ Significantly different from the same sex in Langland Bay (Fishers exact-test, p < 0.05)

\begin{tabular}{|lcc|}
\hline Sex & $\begin{array}{c}\text { Prevalence } \\
\text { \% of crabs } \\
\text { with lesions }\end{array}$ & $\begin{array}{c}\text { Severity } \\
\text { Mean \% cover of } \\
\text { diseased crabs } \pm 1 \text { SE }\end{array}$ \\
\hline $\begin{array}{l}\text { Langland } \\
\text { Male (n =63) }\end{array}$ & 76.2 & $1.0 \pm 0.22$ \\
Female (n = 57) & 43.9 & $0.2 \pm 0.02$ \\
Rhossili & & \\
Male (n=72) & 61.1 & $0.4 \pm 0.09^{*}$ \\
Female (n=32) & $21.9^{*}$ & $0.1 \pm 0.03$ \\
\hline
\end{tabular}

prevalences of infection than females (Table 1). Although no significant difference was found in the prevalence of shell disease amongst males from the 2 sites (Fisher's exact test, $\mathrm{p}=0.0669$ ), significantly lower severities were observed in Rhossili males (Student's $t$-test, $\mathrm{p}=0.0180$ ). Females showed a different pattern, with significantly lower prevalences in Rhossili (Fisher's exact test, $\mathrm{p}=0.0420$ ) and low, but nonsignificant, severities at both sites (Student's $t$-test, $\mathrm{p}=$ 0.2933).

Because of the observed differences in the severity of disease in male crabs and the lower sample numbers of females at Rhossili, investigations into size class and regional infections were restricted to male crabs only (Figs. 3 to 5). At both sample sites, shell disease was most prevalent in males from the 120 to $139 \mathrm{~mm}$ size class (Fig. 3A), but there were no significant differences among males of the same size classes from either Langland or Rhossili (Fisher's exact test, $\mathrm{p}>0.05$ for all size classes). The proportions of the carapace covered by lesions at the 2 sample sites were comparable for the 3 smallest size classes (Fig. 3B). However, significantly greater severities of disease were found in males of the 120 to $139 \mathrm{~mm}$ Langland size class compared to the equivalent in Rhossili (Mann-Whitney $U$ test, $\mathrm{p}=0.015$ ).

No significant differences were found in anatomical distribution of lesions between Langland and Rhossili (Fisher's exact test, p > 0.05 for each anatomical region) (Fig. 4A). However, male crabs showed significantly greater severities of shell disease on the dorsal carapace and abdominal area in Langland compared to Rhossili (Student's $t$-test, $\mathrm{p}<0.05$ ) (Fig. 4B). When male crabs were scored according to the ventral surfaces surrounding the branchial chambers (i.e. all ventral surfaces except the dactylus, propodus and carpus on each pereiopod) disease prevalences were $54.0 \%$ in Langland and $40.28 \%$ in Rhossili (Fisher's exact test, $p=0.1229$ ). Significantly greater ventral surface sever- 

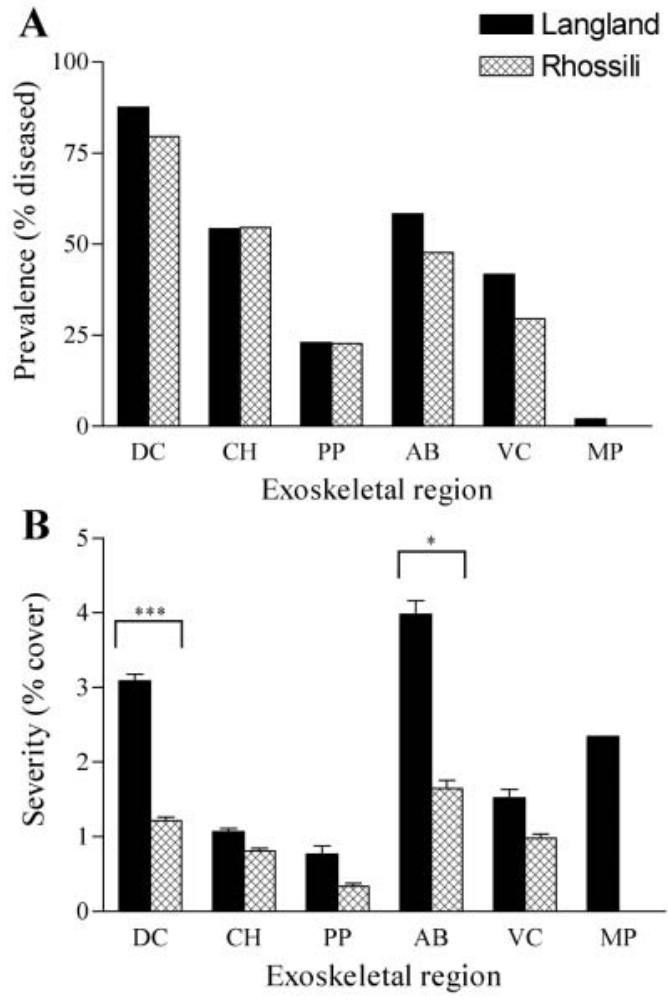

Fig. 4. Cancer pagurus. (A) Prevalence and (B) severity of shell disease in various anatomical regions of the exoskeleton in diseased males sampled at Langland $(\mathrm{n}=48)$ and Rhossili $(\mathrm{n}=44)$ during the 1998 crabbing season. AB: abdominal area (abdomen + thoracic sternum); $\mathrm{CH}$ : cheliped; DC: dorsal carapace; MP: mouth parts; PP: pereiopods 2 to 5, VC: ventral carapace. * Significant, **** very highly significant differences between the same anatomical regions in crabs from Langland and Rhossili (Student's t-test, $\mathrm{p}<0.05$ and $\mathrm{p}<0.001$ respectively)

ities were found at Langland $(1.0 \pm 0.29 \%$ cover $)$ than Rhossili (0.5 $\pm 0.10 \%$ cover) (Student's $t$-test, $\mathrm{p}=$ 0.0495).

Division of the dorsal carapace into 28 equal areas revealed that, for both sample sites, the most commonly infected areas were along the posterior shell margins (Fig 5). The male crabs collected in Langland displayed a graded increase in infection towards the centre of the posterior margins. A similar pattern was also seen in the severity of Langland individuals, with the most severely affected areas located both centrally and toward the rear of the dorsal carapace. In contrast, Rhossili males showed both lower prevalences and significantly lower severities than their Langland counterparts (Student's $t$-test, $\mathrm{p}=0.0001$ ). Maximal values of severity were not restricted to the posterior margins but were located both in the centre regions of the dorsal carapace and on lateral margins.

Bacterial populations from sediment samples that were cultured in minimal media containing powdered chitin $(10 \%)$ as the sole nutrient source, showed a significantly higher chitinase activity (means $\pm 1 \mathrm{SE}$, $\mathrm{n}=10$ ) of $1.57 \pm 0.19 \mu \mathrm{mol}$ GlcNac production $\mathrm{ml}^{-1} \mathrm{~h}^{-1}$ in Langland compared to $0.74 \pm 0.14 \mu \mathrm{mol}$ GlcNac production $\mathrm{ml}^{-1} \mathrm{~h}^{-1}$ in Rhossili (Mann-Whitney $U$-test, $\mathrm{p}=0.0076)$

\section{DISCUSSION}

Similar patterns in the prevalence of shell disease existed in Langland and Rhossili. As in Langland, Rhossili male crabs were more commonly infected than females and displayed higher prevalences of shell disease in the larger size classes. As discussed by Vogan et al. (1999), the longer intermoult period of larger crabs (Edwards 1979) would increase the potential for epicuticular damage and lesion formation, whereas the sexual differences in the prevalence of shell disease are likely to result from differences in aggression, mating behaviour and back-burrowing activities.

Significant variations were found in the severities of shell disease between the 2 sample sites. In particular, the larger male crabs from Langland displayed greater severities of shell disease on their dorsal carapace and ventral surfaces. As in previous studies (Vogan et al. 1999) these patterns are indicative of the epicuticular

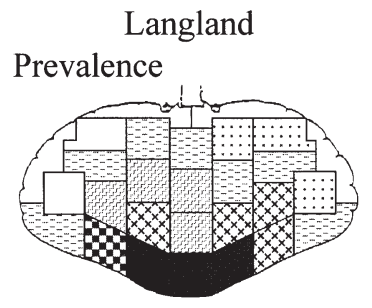

Rhossili

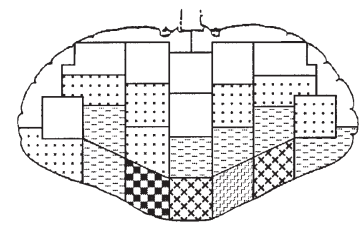

Percentage diseased

$\begin{array}{lllllll}0-10 & 10-20 & 20-30 & 30-40 & 40-50 & 50-60 & >60\end{array}$

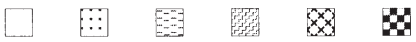

$$
\begin{aligned}
& <3 \quad 3-5 \quad 5-7 \quad 7-9 \quad 9-11 \quad 11-13 \quad>13
\end{aligned}
$$

Severity
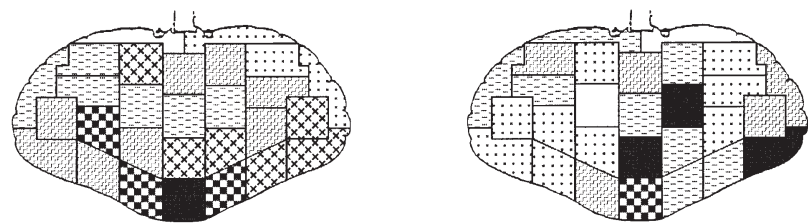

Fig. 5. Cancer pagurus. Diagrammatic representation of distribution of shell disease lesions on the dorsal carapace of males from Langland and Rhossili during the 1998 crabbing season. Prevalence data were calculated using only those crabs that were positive for dorsal carapace infection (Langland $n=42$; Rhossili $n=35$ ). Severity data were calculated as an average percentage cover on those crabs that had dorsal carapace infection in each region 
abrasion by sandy sediments during back-burrowing activities and close contact of newly exposed chitin to large numbers of sediment-dwelling chitinolytic bacteria. The physical nature of the sediment in Rhossili makes it impossible for males to back burrow in the same manner as in Langland. Thus, avoidance of predators and desiccation at low tide is likely to cause Rhossili crabs to retreat to the back of their holes, which will lead to rock abrasion injuries predominantly to the rear and lateral margins of the dorsal carapace. The lack of symmetry in lesion distribution of the dorsal carapace of crabs collected from Rhossili further supports the idea of incidental abrasive injuries to crabs emerging from holes at low tide or exposed to flying shell debris during surging tides. The inability to back-burrow into sediment also means that the Rhossili crabs are exposed to significantly lower numbers of chitinolytic microorganisms contained within the water column compared to such microbes within the sediments.

Environment Agency (UK) data suggest that the waters around Langland contain higher numbers of coliform bacteria than waters arount Rhossili, with seasonal averages in 1998 of $11.2 \pm 5.7$ and $0.8 \pm 0.5$ coliforms $\mathrm{ml}^{-1}$ for Langland and Rhossili Bay respectively (www.environment-agency.gov.uk). Lower chitinolytic activities in cultured sediment from Rhossili (compared to Langland Bay) combined with the inability to backburrow in many areas of the Rhossili causeway, probably results in the lower levels of shell disease observed at the latter site.

Shell disease in natural populations of crustaceans has frequently been correlated with pollution (e.g. Gopalan \& Young 1975, Young \& Pearce 1975, Sawyer 1991). However, a number of other studies have concluded that water and sediment quality are not the primary source of elevated levels of shell disease in crustaceans (e.g. Nottage 1982, Young 1991, Dyrynda 1998). The potential link between environmental quality and shell disease could arise via a number of mechanisms. For example, an increase in organic matter as a result of faecal pollution could lead to elevated numbers and diversity of chitinolytic bacteria, hence increasing the chance of lesion formation. The chitinolytic activities of such bacteria may also be enhanced by environmental factors, thus encouraging cuticle degradation. Reduced environmental quality could also result in suppression of immune competence in crustaceans (Noga et al. 1994). Noga et al. reported reduction in natural humoral antibacterial activity in the blood of blue crabs Callinectes sapidus in sites of varying water quality in the AlbermarlePamlico Estuary (North Carolina, USA). They argued that such reductions could also have an effect on growth of bacteria in cuticular lesions.
Swansea Bay is known to receive sewage and industrial waste discharges from a number of sites, as well as having dredged spoil grounds within its sedimentary system (Shackley 1986). Murray et al. (1980) found that a higher organic content in the outer Swansea Bay was related to a greater mud content and it is well established, from many studies in different locations, that high bacterial abundances exist in sediments containing high levels of organic matter (Cammen 1982, Yamamoto \& Lopez 1985, Sander \& Kalff 1993). Although, in the present study, no accurate assessment was made of bacterial content at both sites, it is assumed that Langland, with its closer proximity to Swansea Bay, finer grain size and higher coliform counts, is more polluted by sewage and industrial inputs than Rhossili.

Overall, this study has shown a correlation between levels of activity of chitinolytic bacteria and shell disease severity. Whether the higher levels of chitinase activity result from pollution and/or differences in sediment type needs further investigation. The study has also highlighted that differences in the levels of shell disease in benthic species between 2 or more sample sites cannot be directly attributed to pollution differences unless the sites are geographically close and of similar substratum type.

Acknowledgements. We thank Paul Llewellyn and Wyn Morris for their expert knowledge of the shore and assistance with field collection and the National Trust for granting vehicle access at Rhossili. C.L.V. was supported by a University of Wales studentship.

\section{LITERATURE CITED}

Anderson JIW, Conroy DA (1968) The significance in preliminary attempts to raise Crustacea in sea water. Bull Off Int Epizoot 69:1239-1247

Cammen LM (1982) Effect of particle-size on organic content and microbial abundance within 4 marine-sediments. Mar Ecol Prog Ser 9:273-280

Chan S, Rankin SM, Keeley LL (1988) Characterisation of the molt stages in Penaeus vannamei: setogenesis and haemolymph levels of protein, ecdysteroids and glucose. Biol Bull 175:185-192

Cipriani GR, Wheeler RS, Sizemore RK (1980) Characterization of brown spot disease of Gulf Coast shrimp. J Invertebr Pathol 36:255-263

Delves-Broughton J, Poupard CW (1976) Disease problems of prawns in recirculation systems in the UK. Aquaculture 7: 201-217

Drach P (1939) Mue et cycle d'intermue chez lea crustaces decapodes. Ann Inst Océanogr 19:103-391

Dyrynda EA (1998) Shell disease in the common shrimp Crangon crangon: variations within an enclosed estuarine system. Mar Biol 132:445-452

Edwards E (1979) The edible crab and its fishery in british waters. Fishing New Books, Farnham, Surrey 
Estrella BT (1990) Shell disease in the American lobster off the Massachusetts coast. J Shellfish Res 8:461

Getchell RG (1989) Bacterial shell disease in crustaceans: a review. J Shellfish Res 8:1-6

Getchell RG (1991) Lobster shell disease survey. J Shellfish Res 10:489-490

Gopalan UK, Young JS (1975) Incidence of shell disease in shrimp in the New York Bight. Mar Pollut Bull 6:149-153

Hood MA, Meyers SP (1973) The biology of aquatic chitinoclastic activities. Mer (Tokyo) 11:213-229

Murray LA, Norton JH, Nunny RS, Rolfe MS (1980) The filed assessment of effects of dumping waste at sea. 7: Sewage sludge and industrial waste disposal in the Bristol Channel. Ministry of Agriculture, Fisheries and Food Directorate of Fisheries Research, Lowestoft

Noga EJ, Engel DP, Arroll TW, McKenna S, Davidian M (1994) Low serum antibacterial activity with increased prevalence of shell disease in blue crabs, Callinectes sapidus. Dis Aquat Org 19:121-128

Nottage AS (1982) Shell disease in the brown shrimp, Crangon crangon (L.), and other marine crustaceans. Chem Ecol 1:107-123

Prince DL, Bayer RC, Loughlin M (1993) Etiology and microscopy of shell disease in impounded American lobsters, Homarus americanus. Bull Aquac Assoc Can 4: 87-89

Sander BC, Kalff J (1993) Factors controlling bacterial production in marine and fresh water sediments. Microb Ecol 26:79-99

Sawyer TK (1991) Shell disease in the Atlantic rock crab, Can-

Editorial responsibility: Jo-Ann Leong,

Corvallis, Oregon, USA cer irroratus Say, 1817, from the northeastern United States. J Shellfish Res 10:495-497

Schlotfeldt HJ (1972) Jahreszeitliche Abhängigkeit der 'Schwarzfleckenkrankheit' bei der Garnele, Crangon crangon (L). Ber Dtsch Wiss Komm Meeresforsch 22:397-399

Shackley SE (1986) Trace metal inputs to an industrial embayment related to concentrations in benthic fauna and sediments. Rapp P-V Réun Cons Int Explor Mer 186:449-467

Vogan CL, Llewellyn PJ, Rowley AF (1999) Epidemiology and dynamics of shell disease in the edible crab Cancer pagurus: a preliminary study of Langland Bay, Swansea, UK. Dis Aquat Org 35:81-87

Vogan CL, Costa-Ramos C, Rowley AF (2002) Shell disease syndrome in the edible crab, Cancer pagurus-isolation, characterization and pathogenicity of chitinolytic bacteria. Microbiology (Reading) 148:743-754

Warner GF (1977) The biology of crabs. Elek Science, London

Yamamoto N, Lopez G (1985) Bacterial abundance in relation to surface area and organic content of marine sediments. J Exp Mar Biol Ecol 90:209-220

Yanai K, Takaya N, Kojima N, Horiuchi H, Ohta A, Takagi M (1992) Purification of two chitinases from Rhizopus oligosporus and isolation and sequencing of the encoding genes. J Bacteriol 174:7398-7406

Young JS (1991) Prevalence and severity of shell disease among deep-sea red crabs (Chaceon quinquedens, Smith 1879) in relation to ocean dumping of sewage sludge. J Shellfish Res 10:499-503

Young JS, Pearce JB (1975) Shell disease from crabs and lobsters from New York Bight. Mar Pollut Bull 6:101-105

Submitted: December 3, 2001; Accepted: April 29, 2002

Proofs received from author(s): September 26, 2002 